\title{
Sosialisasi Laporan Keuangan UMKM dalam Rangka Membantu Program Kewirausahaan di Yayasan Al-Khoiriyah
}

\author{
Neneng Nurhasanah ${ }^{\mathrm{a}, 1}$, Dian Widiyatib ${ }^{\mathrm{b}, 2}$, Fitriyah ${ }^{\mathrm{c}, 3}$, Andry Sugeng ${ }^{\mathrm{d}, 4}$ dan Agus Afandi ${ }^{\mathrm{e}, 5}$ \\ a,b,c,d,eProdi S1 Akuntansi, Fakultas Ekonomi, Universitas Pamulang* \\ Email:* dosen02422@unpam.ac.id
}

\begin{abstract}
Abstrak
UMKM di Tangerang Selatan harus dapat mendukung peningkatan daya saing perekonomian Provinsi Banten, pertumbuhan ekonomi, pengurangan kemiskinan, dan peningkatan standar hidup penduduk di Provinsi Banten. Oleh karena UMKM harus dapat bersaing dan mampu menangkap setiap kesempatan yang ada agar tetap dapat berkiprah dalam perekonomian nasional. Hal ini disebabkan banyaknya UMKM lebih berfokus pada kegiatan operasional sehingga pencatatan dan pelaporan seringkali terabaikan. Tanpa catatan dan laporan yang baik evaluasi kinerja UMKM tidak mudah untuk dilakukan. Yayasan Al-khoiriyah mempunyai program kewirausahaan untuk para remaja yang bertujuan untuk mensejahterakan hidup mereka. Dalam program menciptakan wirausaha di Yayasan Al-khoiriyah para peserta dibekali ilmu dan pengetahuan tentang penyusunan laporan keuangan UMKM, keterbatasan sumber daya manusia untuk mengenali laporan keuangan, dan latar belakang pendidikan juga menjadi alasan mereka belum dapat mensosialisasikan laporan keuangan. Tujuan pengabdian masyarakat ini untuk memberikan sosialisai tentang berwirausaha dan menyusun laporan keuangan UMKM secara teori dan praktik. Metode yang digunakan adalah seminar dan penyampaian materi secara langsung serta simulasi dan diskusi mengenai laporan keuangan UMKM dalam program kewirausahaan. Kesimpulan dari pengabdian kepada masyakat ini adalah remaja dan pengurus Yayasan yang sudah menjalani usaha secara mandiri semoga dapat menyusun laporan keuangan UMKM guna untuk mengetahui keberlangsungan usahanya dan dapat dijadikan syarat untuk mendapatkan tambahan modal usaha meraka.
\end{abstract}

Kata-kata kunci: UMKM; laporan keuangan; kewirausahaan

\begin{abstract}
UMKM in South Tangerang must be able to support the improvement of the economic competitiveness of Banten Province, economic growth, poverty reduction, and improvement of the standard of living of the population in Banten Province. Therefore, UMKM must be able to compete and be able to seize every opportunity so that they can continue to take part in the national economy. This is because many UMKM is more focused on operational activities so that recording and reporting are often neglected. Without good records and reports, UMKM performance evaluation is not easy to do. The Al-khoiriyah Foundation has an entrepreneurship program for teenagers that aims to make their lives prosperous. In the program to create entrepreneurs at the AlKhoiriyah Foundation, the participants were provided with knowledge and knowledge about the preparation of UMKM financial reports, limited human resources to recognize financial reports, and educational background were also reasons they had not been able
\end{abstract}


to disseminate financial reports. The purpose of this community service is to provide socialization about entrepreneurship and compile MSME financial reports in theory and practice. The method used is seminars and direct delivery of the material as well as simulations and discussions on UMKM financial reports in entrepreneurship programs. This community service concludes that teenagers and foundation administrators who have been running businesses independently hope to be able to compile UMKM financial reports to determine the sustainability of their business and can be used as a condition for getting additional business capital for them..

Keywords: UMKM; Finansial report; Entrepreneur

\section{PENDAHULUAN}

Usaha Mikro Kecil dan Menengah (UMKM) berperan penting dalam perekonomian Indonesia. Hal tersebut dapat dilihat dari kedudukan dan fungsi penting yang secara bersama-sama dengan badan usaha milik negara atau swasta dalam melakukan berbagai usaha demi tercapainya kesejahteraan bagi masyarakat. Fungsi UMKM yaitu, sebagai usaha dalam mempersatukan, mengarahkan dan mengembangkan daya kreasi, daya cipta, serta daya usaha rakyat, terutama mereka yang serba terbatas kemampuan ekonominya agar mereka dapat turut serta dalam kegiatan perekonomian. UMKM berperan mempertinggi taraf hidup dan membuka lapangan kerja baru bagi masyarakat pada umumnya (Yuniarta, 2013).

UMKM di Tangerang Selatan harus dapat mendukung peningkatan daya saing perekonomian Provinsi Banten, pertumbuhan ekonomi, pengurangan kemiskinan, dan peningkatan standar hidup penduduk di
Provinsi Banten. Oleh karena UMKM harus dapat bersaing dan mampu menangkap setiap kesempatan yang ada agar tetap dapat berkiprah dalam perekonomian nasional. Segala bentuk upaya pemecahan masalah atas berbagai kendala yang dihadapi UMKM dalam peningkatan kinerjanya. Hal ini disebabkan banyak UMKM lebih berfokus pada kegiatan operasional sehingga pencatatan dan pelaporan seringkali terabaikan. Tanpa catatan dan laporan yang baik evaluasi kinerja UMKM tidak mudah untuk dilakukan.

Pengelolaan keuangan menjadi salah satu aspek penting bagi kemajuan perusahaan. Pengelolaan keuangan dapat dilakukan melalui akuntansi. Akuntansi merupakan proses sistematis untuk menghasilkan informasi keuangan yang dapat digunakan untuk pengambilan keputusan bagi penggunanya. Sepanjang UMKM masih menggunakan uang sebagai alat tukarnya, akuntansi sangat dibutuhkan oleh UMKM. Akuntansi akan memberikan beberapa 
manfaat bagi pelaku UMKM, antara lain UMKM dapat mengetahui kinerja keuangan perusahaan, UMKM dapat mengetahui, memilah, dan membedakan harta perusahaan dan harta pemilik, UMKM dapat mengetahui posisi dana baik sumber maupun penggunaannya, UMKM dapat membuat anggaran yang tepat, UMKM dapat menghitung pajak, dan UMKM dapat mengetahui aliran uang tunai selama periode tertentu. Melihat manfaat yang dihasilkan akuntansi, pelaku UMKM seharusnya sadar bahwa akuntansi penting bagi perusahaan mereka. Penggunaan akuntansi dapat mendukung kemajuan UMKM khususnya dalam hal keuangan. Peningkatan laba juga dapat direncanakan dengan menggunakan akuntansi. Dengan tingkat laba yang semakin meningkat, perkembangan UMKM akan menjadi lebih baik sehingga UMKM akan benar-benar menjadi salah satu solusi bagi masalah perekonomian di Indonesia. Namun, masih banyak UMKM yang belum menggunakan akuntansi dalam menunjang kegiatan bisnisnya. Alasan pelaku UMKM tidak menggunakan akuntansi antara lain adalah akuntansi dianggap sesuatu yang sulit dan tidak penting. Beberapa pelaku UMKM mengatakan bahwa tanpa akuntansi pun perusahaan tetap berjalan lancar dan selalu memperoleh laba. Edukasi dan sosialisasi dibutuhkan agar masyarakat memperoleh pengetahuan dan ketrampilan untuk mengelola sumber dayanya lebih baik lagi (Irawati, W., et al, 2019)

Laporan Keuangan berfungsi sebagai alat untuk menganalisis kinerja keuangan yang dapat memberikan informasi tentang posisi keuangan, usaha, kinerja dan arus kas sehingga dapat dijadikan dasar membuat keputusan-keputusan ekonomi. Laporan keuangan UMKM (Usaha Mikro Kecil Menengah) sangat sederhana dan cenderung mengabaikan kaidah administrasi keuangan yang standar. Kini di Indonesia, terdapat standar pelaporan keuangan khusus UKM atau UMKM (Usaha Mikro Kecil Menengah) yang bisa dijadikan contoh. Peraturan atau standar tersebut dinamakan SAK EMKM (Standar Akuntansi Keuangan Entitas Mikro Kecil Menengah).

$$
\text { Faktanya UMKM menghadapi }
$$
berbagai kendala atau masalah yang disebabkan beberapa faktor yaitu: rendahnya pendidikan, kurangnya pemahaman teknologi informasi, dan kurangnya keandalan karakteristik laporan keuangan. Pendidikan yang diartikan sebagai proses pembelajaran untuk meningkatkan pengetahuan yang diperoleh melalui pendidikan formal dan non formal. Pelaku usaha sektor kecil hendaknya memahami teknologi informasi, agar apa yang telah direncanakan dan diprogramkan dapat dijalankan. Dalam menyusun laporan 
keuangan harus memenuhi karakteristik kualitatif laporan keuangan (Sariningtyas,2012).

Yayasan Al-khoiriyah mempunyai program kewirausahaan untuk para remaja yang bertujuan untuk mensejahterakan hidup mereka. Menurut catatan Dinas koperasi Tangerang selatan pada tahun 2018 tercatat 26.700 UMKM. Dari data tersebut, sebagian besar usahanya bergerak di bidang kuliner. Dalam program menciptakan wirausaha di Yayasan Al-khoiriyah para peserta dibekali ilmu dan pengetahuan tentang penyusunan laporan keuangan UMKM, keterbatasan sumber daya manusia untuk mengenali laporan keuangan, dan latar belakang pendidikan juga menjadi alasan mereka belum dapat mensosialisasikan laporan keuangan.

Praktik pengabdian masyarakat ini secara umum bertujuan untuk mensosialisasikan laporan keuangan UMKM dalam rangka membantu program kewirausahaan di Yayasan Al-khoiriyah, Sawah Baru, Ciputat. Banyaknya pelaku wirausaha yang belum mengetahui laporan keuangan UMKM yang sesuai dengan SAKEMKM membuat kami ingin mensosialisasikan hal tersebut kepada mereka. Dengan adanya laporan keuangan UMKM yang sesuai maka dapat membantu mereka untuk menilai kinerja usahanya, sehingga usaha yang mereka lakukan dapat terlihat maksimal dengan menggunakan laporan keuangan yang mereka susun secara mandiri. Selain untuk melihat kinerja usaha mereka, laporan keuangan yang telah tersusun rapih dapat berguna untuk mengajukan bantuan modal usaha kepada pemerintah setempat. Sedangkan secara khusus tujuan kegiatan pengabdian kepada masyarakat ini adalah Membantu untuk mengembangkan program kewirausahaan di Yayasan AlKhoiriyah dan juga membantu pengurus Yayasan dalam meningkatkan kualitas SDM yang baik dan unggul dalam hal berwirausaha dan mengetahui laporan keuangan UMKM dengan baik

Manfaat dari Pengabdian Kepada Masyarakat ini yaitu pertama membantu Yayasan Al-khoiriyah dalam menjalankan program kewirausahaannya terutama dalam menyusun laporan keuangan UMKM, dan juga memberi manfaat terhadap akademisi menjadi wadah untuk memberikan dan menyalurkan ilmu pengetahuan yang dimiliki.

Berdasarkan latar belakang tersebut, kami dari Tim Program Pengabdian Masyarakat (PKM) Universitas Pamulang (UNPAM) yang berjumlah lima dosen terpanggil untuk ikut serta membantu melakukan sosialisasi, penyuluhan dan penyampaian materi untuk laporan keuangan 
UMKM dalam pelaksanaan Program

Kewirausahaan di Yayasan Al-khoiriyah.

\section{METODE}

Kegiatan pengabdian kepada masyarakat ini dilaksanakan di Yayasan Alkhoiriyah yang beralamat dijalan $\mathrm{H}$ toha dulhalim rt 005 rw 004 no.29 kelurahan sawah baru kecamatan ciputat kota tangerang selatan provinsi banten pada hari rabu, 4 desember 2019. Metode pelaksanaan pengabdian ini dilakukan dalam beberapa kegiatan yaitu pertama, Tahap Persiapan meliputi : (1). Survey awal, pada tahap ini dilakukan survey langsung ke lokasi. (2) Pemantapan dan penentuan lokasi sasaran, setelah survey maka ditentukan lokasi pelaksanaan dan sasaran peserta kegiatan (3). Penyusunan bahan/materi sosialisai dan penyuluhan, meliputi slide dan makalah. Kedua, Tahap Pelaksanaan Sosialisasi dan penyuluhan. Tahap ini akan dilakukan penjelasan mengenai penyusunan dan pencatatan laporan keuangan UMKM dan kewirausahaan. Selanjutnya, metode Tanya Jawab. Metode tanya jawab sangat penting bagi para peserta yang hadir. Metode ini memungkinkan peserta dapat menggali sebanyak - banyaknya tentang pentingnya penyusunan dan pencatatan laporan keuangan UMKM.

\section{HASIL DAN PEMBAHASAN}

Kegiatan pengabdian kepada masyarakat yang diselenggarakan di Yayasan Alkhoiriyah, Kota Tangerang Selatan, Banten berjalan dengan baik dan lancar yang diselenggarakan oleh Tim Dosen Universitas Pamulang Tangerang. Universitas Pamulang (UNPAM) merupakan kampus yang berdiri di bawah naungan Yayasan Sasmita Jaya yang beralamat di Jl. Surya Kencana No. 1 Pamulang. UNPAM membuka diri untuk melakukan berbagai kerjasama dengan berbagai pihak dalam rangka pengembangan ilmu, institusi, teknologi dan seni dalam rangka pelaksanaan Tri Dharma Perguruan Tinggi yakni Pendidikan, Penelitian dan Pengabdian. UNPAM sudah mempunyai jaringan dengan berbagai lembaga lain yakni pemerintah pusat, pemerintah propinsi, pemerintah kabupaten, dunia usaha, swasta maupun dengan masyarakat.

Pertama kali kami melakukan survey lokasi yang akan dijadikan tempat untuk pengabdian kepada masyarakat di Yayasan Al-khoiriyah. Kemudian dilanjutkan dengan pengajuan proposal pengabdian kepada masyarakat dengan judul "Sosialisasi Laporan Keuangan Dalam Rangka Membantu Program Kewirausahaan Di Yayasan Al-khoiriyah Kota Tangerang Selatan - Banten Tanggal 04 Desember 2019”. Setelah proposal disetujui, kami 
melakukan persiapan materi dan bahan bahan yang akan digunakan dalam kegiatan ini. Persiapan ini dilakukan agar peserta dapat dengan mudah memahami materi yang kami berikan. Tujuan dari persiapan tersebut kami lakukan agar praktik pengabdian kami berjalan dengan lancar serta dapat sambutan yang positif dari para peserta.

Melihat kondisi potensi kewirausahaan sebagian besar adalah kalangan muda maka diperlukan pengetahuan wawasan kepada para pemuda mengenai wawasan kewirausahaan dan laporan keuangannya.Pemuda mempunyai kreatifitas dan inovasi tinggi namun mereka awam dengan pengelolaan sebuah usaha karena tidak memahami pencatatan dan penyusunan laporan keuangan.

\section{Kewirausahaan}

Wirausaha adalah orang yang pandai dan berbakat mengenali produk baru yang bermanfaat bagi masyarakat, menentukan cara produksi baru, menyusun operasi (tindakan) untuk pengadaan produk baru, memasarkan, dan mengatur permodalan operasinya. Singkatnya, wirausaha adalah orang yang secara mandiri mengelola seluruh hal-hal yang berkaitan dengan produksi dan penjualan suatu barang yang bermanfaat bagi masyarakat. Untuk memulai suatu usaha sendiri bukanlah hal yang mudah, tetapi dibutuhkan motivasi yang tinggi dan kiat-kiat untuk bertahan dan meraih kesuksesan.
Adapun kiat-kiatnya antara lain: Percaya diri, Optimis, Berani mencoba, Berani bermimpi, Kreatif, Pandai melihat peluang, Tidak malu, Berani beda, Jujur dan Menepati janji.

Banyak klasifikasi yang diberikan oleh para ahli ekonomi maupun psikologi tentang sifat-sifat yang harus dimiliki oleh wirausaha. Bygrave mengembangkan 10 sifat yang harus dimiliki oleh wirausaha. Sifat atau karakteristik wirausaha dikenal dengan istilah 10 D. Kesepuluh sifat tersebut adalah: Dream (mimpi) terhadap keinginan masa depan pribadi dan bisnis serta mampu mewujudkan mimpinya, Decisiveness (bekerja cepat) membuat keputusan secara cepat dan penuh perhitungan, Doers (keputusan segera ditindaklanjuti) tidak menunda-nunda kesempatan, Determination atau melaksanakan kegiatan dengan penuh perhatian, rasa tanggung jawab tinggi \& tidak menyerah meski dihadapkan pada halangan dan rintangan yang berat, Dedication (rasa pengorbanan yang tinggi), Devotion artinya kegemaran atau kegila-gilaan dalam mencintai bisnisnya, Details yakni memperhatikan faktor-faktor kritis secara rinci, Destiny artinya bertanggung jawab terhadap nasib dan tujuan yang hendak dicapai. Bebas dan tidak tergantung kepada orang lain. Dollars berarti motivasinya tidak semata-mata mencari uang, tetapi uang merupakan tolok ukur keberhasilan bisnisnya. 
Mereka berasumsi jika sukses berbisnis, maka pantas mendapatkan laba / bonus / hadiah dan terakhir Distribute yakni bersedia mendistribusikan kepemilikan bisnisnya terhadap orang-orang kepercayaannya.

\section{Laporan Keuangan Usaha Menengah Kecil Mikro (UMKM)}

Laporan keuangan UMKM merupakan catatan informasi keuangan suatu perusahaan yang dibuat dalam satu periode akuntansi. Laporan keuangan ini nantinya dapat digunakan untuk menggambarkan kinerja dari suatu perusahaan, tolak ukur pengambilan kebijakan jika ada hal-hal krusial yang terjadi di perusahaan, dan salah satu alat untuk mengurus perpajakan perusahaan itu sendiri. Berkembangnya Teori Akuntansi juga berpengaruh positif terhadap berkembangnya standar-standar akuntansi yang berlaku di tiap negara secara dinamis. Baik standar dari GAAP (Generally Accepted Accounting Principles) dan IFRS (International Financial Reporting Standard) selalu berubah seiring berjalannya waktu. Kini di Indonesia, terdapat standar pelaporan keuangan khusus UKM atau UMKM (Usaha Mikro Kecil Menengah) yang bisa dijadikan contoh. Peraturan atau standar tersebut dinamakan SAK EMKM (Standar Akuntansi Keuangan Entitas Mikro Kecil Menengah).

Sebagai informasi, SAK EMKM merupakan standar yang dibuat dan disahkan langsung oleh Dewan IAI (Ikatan Akuntan Indonesia). Alasan dibuatnya SAK EMKM ini adalah dikarenakan banyak pelaku usaha EMKM atau UMKM yang belum mengetahui cara membuat Laporan Keuangan secara lengkap, mendetail dan komprehensif. Sedangkan Laporan Keuangan merupakan instrumen yang penting bagi kegiatan bisnis dalam melaporkan segala transaksi dari seluruh aktivitas bisnis UMKM.

Pada dasarnya, Laporan Keuangan menurut SAK EMKM dibuat berdasarkan asumsi dasar akrual dan kelangsungan usaha seperti entitas bisnis umumnya. Syarat penyajian Laporan Keuangan UMKM harus bersifat relevan, lengkap, bisa dipahami, dan komparatif. Sesuai dengan peraturan SAK EMKM, minimal UMKM harus membuat tiga jenis laporan keuangan berikut ini: Laporan posisi keuangan, Laporan laba rugi, dan Catatan atas laporan keuangan.

\section{Upaya Pemberian Sosialisasi Laporan Keuangan UMKM}

Pembekalan yang diberikan oleh tim PKM adalah pemberian wawasan mengenai kewirausahaan dan laporan keuangan UMKM untuk menciptakan usahawan muda yang potensial dan mandiri, dan pada akhirnya dapat mengurangi pengangguran secara signifikan.

Dalam kegiatan ini peserta di bekali ilmu dan pengetahuan dalam berwirausaha dan 
menyusun laporan keuangan UMKM serta sesi tanya jawab.

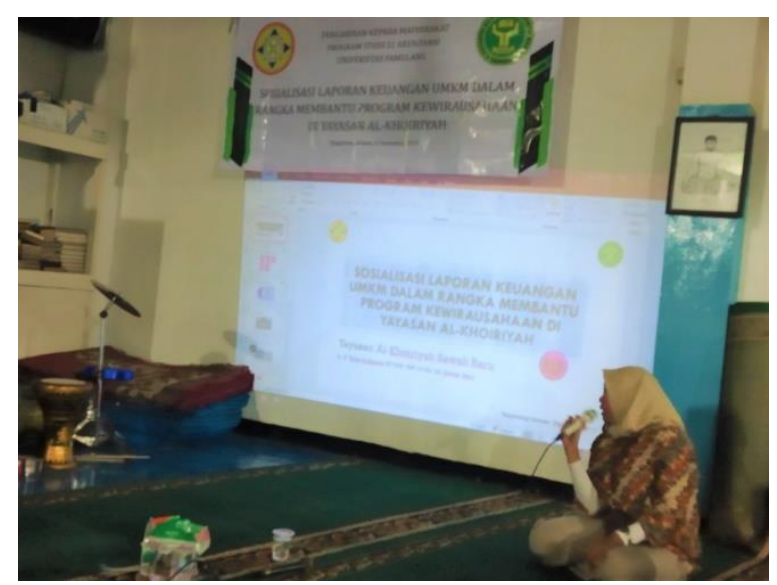

Gambar 1 : Dian Widiyati Sedang Memberikan Materi

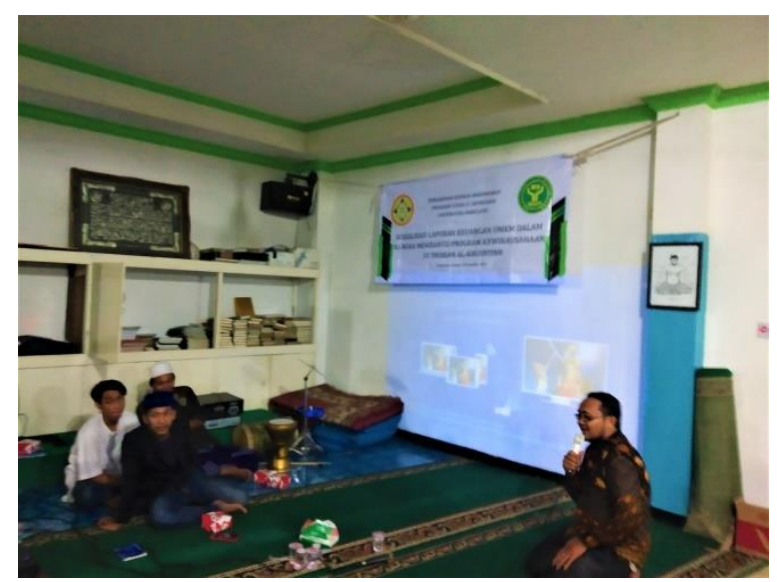

Gambar 2 : Agus Afandi Sedang Memberikan Materi

Gambar 1 dan gambar 2 menunjukkan bahwa Tim PKM sedang memberikan materi dan sosialisasi mengenai kewirausahaan, motivasi dan bagaimana menumbuhkan semangat dalam berwirausaha serta laporan keuangan UMKM secara bergiliran. Materi yang di sampaikan dalam bentuk power point yang menarik dan mudah di pahami.

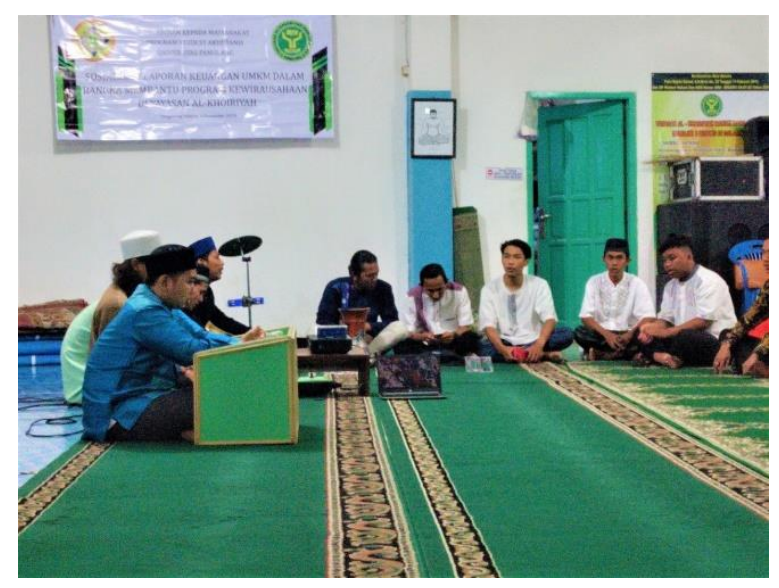

Gambar 3 : Antusiasme peserta

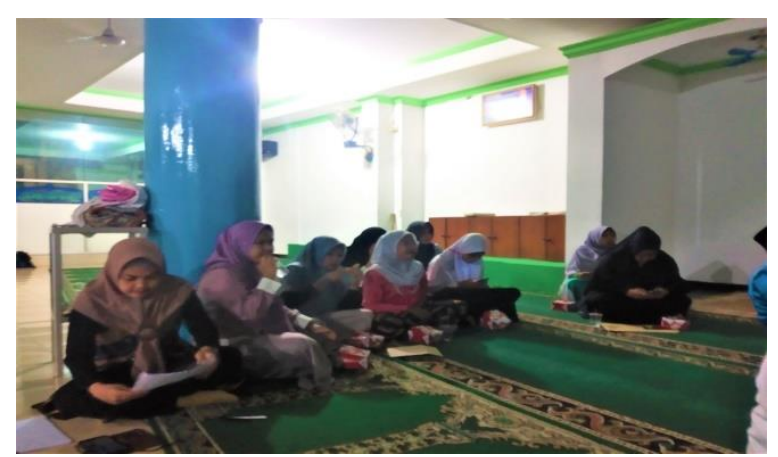

Gambar 4 : Antusiasme peserta

Peserta sangat antusiasme dalam mendengarkan penyampaian materi. Sesi penting selanjutnya adalah Tanya jawab antara peserta dan Tim PKM untuk menggali wawasan kewirausahaan lebih dalam. Permasalahan-permasalahan awal dalam berwirausaha, dan terkait dengan materi yang disampaikan. 


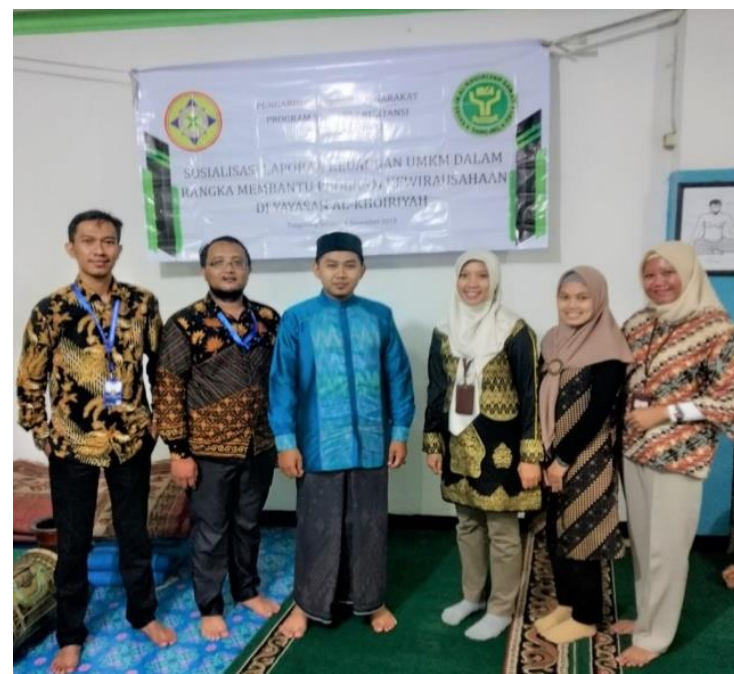

Gambar 5 : Tim PKM dengan Ketua Yayasan Al-khoiriyah

\section{KESIMPULAN DAN SARAN}

\section{Kesimpulan}

Pelaksanaan kegiatan Pengabdian Kepada Masyarakat oleh Lembaga Penelitian dan Pengabdian Masyarakat (LPPM) Universitas Pamulang yang dilakukan oleh dosen-dosen program studi Akuntansi telah berjalan dengan lancar dan mendapat sambutan hangat anak remaja dan pengurus Yayasan AlKhoiriyah. Banyak pertanyaan yang diajukan dari peserta mengenai wirausaha dan laporan keuangan UMKM. Rasa ingin tahu yang begitu tinggi dan rasa dahaga terhadap ilmu pengetahuan tersebut membuat mereka merasa terarahkan dengan adanya pengabdian masyarakat ini.

Dengan adanya praktik pengabdian ini, kami berharap semoga para peserta dan pengurus Yayasan mendapatkan ilmu dan wawasan yang lebih luas lagi mengenai wirausaha dan laporan keuangan UMKM. Bagi remaja pemula diharapkan dapat menjalani usahanya dengan penuh rasa percaya diri dengan kreatifitas dan inovasi yang mereka ciptakan. Untuk remaja dan pengurus Yayasan yang sudah menjalani usaha secara mandiri semoga dapat menyusun laporan keuangan UMKM guna untuk mengetahui keberlangsungan usahanya dan dapat dijadikan syarat untuk mendapatkan tambahan modal usaha meraka.

\section{Saran}

Dalam pelaksanaan kegiatan dan laporan kegiatan ini tentunya masih banyak kekurangan yang ada pada kami. Oleh karena itu Pengabdian selanjutnya lebih ke pendampingan dalam menjalankan wirausaha dan praktik langsung mengenai penyusunan laporan keuangannya. 


\section{REFERENSI}

Azaria, Vina Mukti. (2013). Penerapan Akuntansi pada UKM Unggulan di Kabupaten Kota Blitar dan Kesesuaiannya dengan SAK ETAP.Skripsi. Universitas Jember.

Ikatan Akuntan Indonesia. (2009). Standar Akuntansi Keuangan Entitas Tanpa Akuntabilitas Publik. Dewan Standar Akuntansi Keuangan:Jakarta.

Irawati, W., Annisa, D., Aprilia, E. A., Utami, T., \& Angraini, D. (2019). Pengenalan Dasardasar Investasi bagi Ibu-ibu PKK Kelurahan Babakan, Setu, Tangerang Selatan. ABDIMISI, l(1), 18-23.
Muchid, Abdul. Penyusunan Laporan Keuangan UMKM berdasarkan Standar AkuntansiKeuangan-Entitas Tanpa Akuntabilitas Publik (SAKETAP) (Kasus pada UD.Mebel Novel'l di Banyuwangi). Karya Ilmiah. Jurusan Akuntansi, Fakultas Ekonomi, Universitas Jember (UNEJ).

Shonhadji, Nanang, dkk. (2017). Penerapan Penyusunan Laporan Keuangan pada Usaha Kecil Menenengah Berdasarkan SAK EMKM di Surabaya. Seminar Nasional Hasil Pengabdian kepada Masyarakat (SENIAS). Universitas Islam Madura. 